\title{
Neurologic Intensive Care Unit Catastrophes: Airway, Breathing, and Circulation
}

\author{
Cecil O. Borel, MD
}

\author{
Address \\ Department of Anesthesiology, Duke University Medical Center, \\ Box 3094, Durham, NC 27710, USA. \\ Email: borel001@ mc.duke.edu \\ Current Treatment Options in Neurology 2000, 2:499-506 \\ Current Science Inc. ISSN 1092-8480 \\ Copyright $\odot 2000$ by Current Science Inc.
}

\section{Opinion statement}

When a catastrophic change in a patient occurs during the treatment of an underlying neurologic illness, management must be initiated to prevent secondary organ injury as disease specific treatment begins. Patients should be intubated, ventilated, and perfused, regardless of disease etiology or subsequent specific treatment.

\section{Introduction}

A catastrophic illness causes death within hours. Catastrophic illnesses in the neurologically critically ill patient are either the result of a progression of underlying illness or the result of respiratory or cardiac dysfunction caused by the neurologic disease. Initial management focuses on prevention of secondary systemic injury. Neurologic intensive care unit (ICU) catastrophes result from a "vicious circle" mechanism. Neurologic impairment causes respiratory or circulatory embarrassment, which decreases oxygen delivery to the effected neurons, increasing the neurologic injury and increasing cardiorespiratory dysfunction, ul timately resulting in death. This cycle is most easily broken by supporting respiration and circulation. This prevents increasing neurologic injury resulting from tissue hypoxia, and may allow stabilization enough to initiate disease specific therapy.

The respiratory causes of secondary neurologic injury result from hypoxia or hypercarbia/acidosis. Hypoxia is the result of severely compromised ventilation or inefficient gas exchange, both the result of neurologic injury. Ventilation is compromised by loss of ventilatory drive, airway obstruction, or ventilatory muscle failure Intrapulmonary shunting causes poor gas exchange resulting from aspiration, atel ectasis/ pneumonia, or neurogenic pulmonary edema. Hypercarbia and respiratory acidosis are much less common in catastrophic neurologic illness, because they require adequate oxygenation with insufficient ventilation. This situation is only possible when a patient receives supplemental oxygen, but hypoventilates because of decreased ventilatory drive or muscle weakness.

Circulatory insufficiency resulting in decreased oxygen delivery has large impact on neural tissue, because of the inability of neural tissue to use anaerobic metabolism. Rather than frank cardiac arrest, neurologic catastrophes often begin with bradyarrhythmias and hypotension. Cerebral perfusion pressure and cerebral oxygen delivery can be restored medically with the use of inotropes, vasopressors, and vagolytics.

Brain resuscitation prevents progressive neurologic injury by preventing cell death in ischemic neural tissue. There are few cerebral protection measures currently available that can be applied during a neurologic catastrophe. Nevertheless, any intervention that interrupts the cycle of increasing neurologic injury may offer some degree of neurologic protection and may prove beneficial. 


\section{Treatment}

\section{Interventional procedures}

\section{Circulatory management}

- Oxygen delivery to the brain is dependent on cerebral perfusion pressure, though cerebral blood flow remains constant over a wide range of perfusion pressure, because of cerebral blood flow autoregulaton. When intracranial pressure is low, it is reasonable to consider mean arterial pressure to be the most important component of cerebral perfusion pressure Cerebral blood flow may become compromised at any intracranial pressure when mean arterial pressure falls bel ow $50 \mathrm{~mm} \mathrm{Hg}$ to $60 \mathrm{~mm}$ $\mathrm{Hg}$, because the limits of autoregulation have been exceeded and cerebral blood flow becomes perfusion pressure-dependent.

- Hypotension (systolic blood pressure $<95 \mathrm{~mm} \mathrm{Hg}$ ), in addition to hypoxia $\left(\mathrm{PaO}_{2} \varangle 60 \mathrm{~mm} \mathrm{Hg}\right)$, is an important determinant of outcome from severe head injury amenable to therapeutic manipulation. Twenty-five percent of head injured patients appear to suffer one or more secondary insults during the time between injury and resuscitation [1, Class II; 2, Class II ]. Furthermore, although improved strategies for airway management have decreased the incidence of preresuscitation hypoxia, little progress has been made in ameliorating the influence of hypotension during this period [3••, Class III]. The incidence of hypotension in the ICU also appears to be a significant predictor of poor outcomes independent of etiology and of preresuscitation secondary insult [4, Class III].

- In those patients with spinal cord injury, the primary or mechanical trauma seldom causes total transection, even though the functional loss may be complete The systemic effects of acute spinal cord injury indude hypotension and reduced cardiac output. The local effects indude loss of autoregulation in the injured segment of the spinal cord, and a marked reduction of the microcirculation in both gray and white matter, especially in hemorrhagic regions and adjacent zones. The mi crocirculatory loss extends for a considerable distance proximal and distal to the site of injury. Hypotension results in a dose-dependent reduction of spinal cord blood flow, varying with the severity of injury, and a reduction of spinal cord blood flow, which worsens with time after injury. The functional deficits due to acute spinal cord injury have been measured el ectrophysiol ogically with techniques such as motor and somatosensory evoked potentials, and have been found proportional to the degree of post-traumatic ischemia. The histologic effects include early hemorrhagic necrosis leading to major infarction at the injury site [5, Class III].

- Systemic normotension can be restored with volume expansion or vasopressors (Table 1). Volume expansion improves post-traumatic spinal cord blood flow and spinal cord function measured by evoked potentials. These results provide strong evidence that post-traumatic ischemia is an important secondary mechanism of injury, and that it can be counteracted.

\section{Airway management}

- In the comatose patient, the pharyngeal airway can usually be cleared by extension of the neck at the atlanto-occipital joint [6, Class II]. This maneuver should be avoided in patients with the possibility of unstable cervical spine injuries. The jaw lift maneuver is additionally effective in elevating the tongue off the posterior pharyngeal wall. Although gravity 


\begin{tabular}{|c|c|c|c|c|c|}
\hline Drug & Dosage & $\begin{array}{l}\text { Effect on } \\
\text { blood pressure }\end{array}$ & $\begin{array}{l}\text { Effect on systemic } \\
\text { vascular resistance }\end{array}$ & $\begin{array}{l}\text { Effect on } \\
\text { cerebral flow }\end{array}$ & $\begin{array}{l}\text { Effect on cerebral } \\
\text { vascular resistance }\end{array}$ \\
\hline \multirow[t]{3}{*}{ Dopamine } & $2 \mu \mathrm{g} / \mathrm{kg}$ to $4 \mu \mathrm{g} / \mathrm{kg}$ per minute & None & None & None & None \\
\hline & $4 \mu \mathrm{g} / \mathrm{kg}$ to $8 \mu \mathrm{g} / \mathrm{kg}$ per minute & None & Decrease & Increase & None \\
\hline & $8 \mu \mathrm{g} / \mathrm{kg}$ to $20 \mu \mathrm{g} / \mathrm{kg}$ per minute & Increase & Increase & Large increase & None \\
\hline Phenylepherine & $30 \mu \mathrm{g}$ per minute, titrate & Increase & Increase & Large increase & None \\
\hline Norepinepherine & $2 \mu \mathrm{g}$ per minute, titrate & Increase & Increase & Large increase & None \\
\hline Epinepherine & $2 \mu \mathrm{g}$ per minute, titrate & Increase & Increase & Large increase & None \\
\hline Fluid bolus & 250 cc normal saline & Increase & None & Large increase & None \\
\hline Dobutamine & $2.5 \mu \mathrm{g} / \mathrm{kg}$ per minute & None & Decrease & None & None \\
\hline
\end{tabular}

causes the tongue to obstruct the airway in the supine position, repositioning the patient in lateral decubitus or prone position does not reliably rel ieve the obstruction [7, Class III].

- The ai rway can be secured by tilting the head, placing the thumb and index finger on the mask and remainder of the fingers behind the vertical part of themandible, and then gently lifting the jaw upward to open the collapsed airway. The other hand is then free to operate a resuscitation bag that should be connected to an oxygen source that accommodates $10 \mathrm{~L}$ to $15 \mathrm{~L}$ per minute of oxygen flow rate [8, Class III]. Airway pressures should be maintained less than $20 \mathrm{~cm} \mathrm{H}_{2} \mathrm{O}$ to prevent passive insufflation of the stomach, with associated risk of pulmonary aspiration of gastric contents.

Oral airway

Standard procedure The oral airway is a useful adjunct to maintain airway patency by lifting the tongue off of the posterior pharynx. Placement of an oral airway also has the added advantage of preventing tongue biting during seizures.

Contraindications None reported.

Complications A short oral airway will push the tongue posteriorly with aggravation of the obstruction. An oral airway that is too long pushes the epiglottis down and compresses the larynx reducing the capacity to ventilate, increasing the risk of gastric insufflation.

Special points The cuffed oropharyngeal airway has recently been introduced as an adjunctive airway management procedure, and may offer an effective method of providing an adequate airway for ventilation during resuscitation by hospital staff unskilled in endotracheal intubation $[9 \cdot$, Class II].

Cost/cost effectiveness This is an inexpensive maneuver as the cost of these devices is minimal, and the short-term use may be highly effective.

Nasal airway

Standard procedure The nasal airway is effective in clearing the airway by providing an unobstructed passage between the nose and the retropharynx. Nasal airways are particularly useful for managing the airway for patients who are simultaneously clenching their teeth and obstructing the airway.

Contraindications Nasal tubes must be avoided for patients with facial or basilar skull fractures.

Complications The nasal tube must be lubricated and inserted gently to prevent injury and bleeding in the airway.

Cost/cost effectiveness This is an inexpensive maneuver as the cost of these devices is minimal, and the short-term use is highly effective. 
Laryngeal mask airway

Standard procedure The laryngeal mask airway (LMA) was developed to provide airway patency during general anesthesia without intubation of the trachea or the requirement of laryngoscopy. The LMA has been advocated for use by nonanesthetists at cardiorespiratory arrests. Staff persons not previously trained have been successful using the device following a brief training period [10•, Class II].

The LMA has been modified specifically as an intubating device (ILMA). The ILMA consists of an anatomically curved, short, wide bore, stainless steel tube sheathed in silicone, which is bonded to a laryngeal mask, and a guiding handle. It has a single moveable aperture bar, a guiding ramp, and can accommodate various sizes of spirally wired silicone endotracheal tubes. Endotracheal tube placement does not require movement of the head and neck, or insertion of the fingers in the patient's mouth. This device improves the success rate and ease of intubation in normal patients with cervical stabilization using manual in-line cervical traction $[11 \cdot$, Class II].

Contraindications Patients with full stomachs, vomiting, or bleeding from the upper gastrointestinal tract are not good candidates for the LMA, because the device is not as effective in reducing the risk of pulmonary aspiration as the cuffed endotracheal tube. The LMA does not prevent aspiration of gastric contents, but reduces gastric insufflation during positive pressure ventilation.

Complications When incorrectly placed, the LMA may lead to gastric insufflation or airway obstruction.

Special points The LMA may provide a useful adjunct to airway management for patients with cervical spine injuries by allowing placement of an airway device without neck flexion or laryngoscopy. The LMA may be of further use by guiding a fiberoptic laryngoscope into the trachea or even facilitating blind tracheal intubation by passing an endotracheal tube through the LMA [12, Class II].

Cost/ cost effectiveness This device is expensive relative to other airway devices. The ILMA is reusable.

Endotracheal intubation

Insertion of a cuffed tube through the larynx into the trachea is the standard of care for reliable emergency airway management. This device allows the use of positive pressure ventilation without the concern of gastric insufflation, and thus allows for the use of mechanical ventilation. In addition, endotracheal intubation decreases or prevents the risk of aspiration of gastric contents. Endotracheal intubation should be performed expeditiously with awareness of the potential for increasing neurologic injury during the intubation procedure (Table 2).

\section{Mechanical ventilation}

- Mechanical ventilators perform the neurological ly dependent act of breathing. They can control the brainstem-integrated timing of breathing, and perform the neuromuscular work of breathing. The mode of mechanical ventilation can be prescribed based on the neurologic ventilatory disorder (Table 3).

Controlled ventilation

Standard procedure A controlled mode of mechanical ventilation maintains a minimum level of minute ventilation either in a volume or pressure set mode. A breathing rate is selected to maintain adequate minute ventilation at the tidal volume anticipated by the pressure or volume setting.

Controlled ventilation can be weaned to an assisted mode of ventilation when $\mathrm{PCO}_{2}$ is maintained under adequate pain and sedation management.

Contraindications Controlled modes actually become problematic when ventilatory drive recovers. Breath timing of the ventilator may not match the patient's spontaneous frequency resulting in discoordinated breathing synchrony or "bucking." 


\begin{tabular}{|c|c|c|c|c|}
\hline Impairment & Physiologic confirmation & Indication & $\begin{array}{l}\text { Considerations during } \\
\text { intubation }\end{array}$ & Technique \\
\hline $\begin{array}{l}\text { Decreased level } \\
\text { consciousness }\end{array}$ & GCS $<10$ & $\begin{array}{l}\text { Prevention of } \\
\text { aspiration }\end{array}$ & $\begin{array}{l}\text { Prevent passive regurgita- } \\
\text { tion; minimal sedation is } \\
\text { necessary }\end{array}$ & $\begin{array}{l}\text { Oral tracheal } \\
\text { intubation under direct } \\
\text { laryngoscopy }\end{array}$ \\
\hline $\begin{array}{l}\text { Raised intracranial } \\
\text { pressure }\end{array}$ & $\begin{array}{l}\text { GCS }<9 \\
\text { CT scan }\end{array}$ & $\begin{array}{l}\text { Prevention of } \\
\text { hypoxia or } \\
\text { hypercarbia; } \\
\text { hyperventilation }\end{array}$ & $\begin{array}{l}\text { Block increase in ICP during " } \\
\text { laryngoscopy; prevent } \\
\text { aspiration; avoid } 20 \\
\text { cervical or facial injury }\end{array}$ & $\begin{array}{l}\text { "Rapid sequence" } \\
\text { intubation with cervical } \\
\text { stabilization }\end{array}$ \\
\hline $\begin{array}{l}\text { Posterior fossa } \\
\text { injury not affecting } \\
\text { consciousness }\end{array}$ & $\begin{array}{l}\text { Positional airway } \\
\text { obstruction; decreased } \\
\text { gag reflex }\end{array}$ & $\begin{array}{l}\text { Maintain patent } \\
\text { airway; prevent } \\
\text { aspiration }\end{array}$ & $\begin{array}{l}\text { Exaggerated increased or } \\
\text { decreased blood pressure } \\
\text { response; minimal sedation }\end{array}$ & $\begin{array}{l}\text { Oral tracheal intubation } \\
\text { under direct } \\
\text { laryngoscopy }\end{array}$ \\
\hline Medullary lesion & $\begin{array}{l}\text { Increase resting } \mathrm{PCO}_{2} ; \\
\text { no response to inhaled } \mathrm{CO}_{2}\end{array}$ & $\begin{array}{l}\text { Loss of ventilatory } \\
2 \text { drive }\end{array}$ & $\begin{array}{l}\text { Exaggerated response to } \\
\text { narcotics and sedatives }\end{array}$ & $\begin{array}{l}\text { Oral tracheal intubation } \\
\text { under direct } \\
\text { laryngoscopy }\end{array}$ \\
\hline $\begin{array}{l}\text { High cervical spine } \\
\text { injury }\end{array}$ & $\begin{array}{l}\text { Decrease inspiratory } \\
\text { muscle effort }\end{array}$ & Phrenic paralysis & Avoid $2^{\circ}$ cervical injury & $\begin{array}{l}\text { Best possible cervical } \\
\text { stabilization, fiber } \\
\text { optic intubation, oral } \\
\text { intubation using } \\
\text { LMA, and blind nasal } \\
\text { intubation }\end{array}$ \\
\hline $\begin{array}{l}\text { Lower cervical } \\
\text { thoracic injury }\end{array}$ & $\begin{array}{l}\text { Decrease inspiratory and } \\
\text { expiratory function; } \\
\text { decrease } \\
\mathrm{PO}_{2} 2^{\circ} \text { to atelectasis; } \\
\text { pneumonia }\end{array}$ & $\begin{array}{l}\text { Decrease } \\
\text { intercostal } \\
\text { abdominal strength }\end{array}$ & $\begin{array}{l}\text { Avoid } 2^{\circ} \text { cervical injury; } \\
\text { rigid stabilization already } \\
\text { present; increase } \mathrm{K}^{+} \\
\text {response to succinylcholine }\end{array}$ & $\begin{array}{l}\text { Fiber optic intubation, } \\
\text { oral intubation using } \\
\text { LMA, and blind nasal } \\
\text { e intubation }\end{array}$ \\
\hline $\begin{array}{l}\text { Acute } \\
\text { polyneuropathy }\end{array}$ & 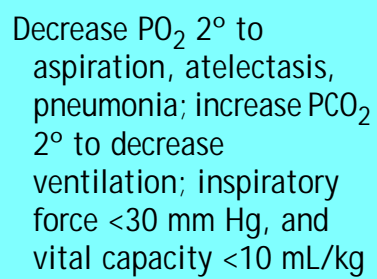 & $\begin{array}{l}\text { Decrease ventilatory } \\
\text { muscle strength; } \\
2 \text { airway obstruction }\end{array}$ & $\begin{array}{l}\text { Dysautonomia exaggerates } \\
\text { decreased blood pressure } \\
\text { with sedation or anesthe- } \\
\text { sia; increase } \mathrm{K}^{+} \text {response to } \\
\text { succinylcholine }\end{array}$ & $\begin{array}{l}\text { Topical local anesthesia; } \\
\text { oral intubation } \\
\text { technique of physician's } \\
\text { choice }\end{array}$ \\
\hline $\begin{array}{l}\text { Neuromuscular } \\
\text { junction disease }\end{array}$ & $\begin{array}{l}\text { Decrease } \mathrm{PO}_{2} 20 \text { to } \\
\text { aspiration, atelectasis, } \\
\text { pneumonia; increase } \mathrm{PCO}_{2} \\
\text { to decrease } \\
\text { ventilation; inspiratory } \\
\text { force }<30 \mathrm{~mm} \mathrm{Hg} \text {, and } \\
\text { vital capacity }<10 \mathrm{~mL} / \mathrm{kg}\end{array}$ & $\begin{array}{l}\text { Decrease ventilatory } \\
\text { muscle strength; } \\
2 \text { airway obstruction }\end{array}$ & $\begin{array}{l}\text { Exaggerated response to } \\
\text { nondepolarizing muscle } \\
\text { relaxant; unpredictable } \\
\text { response to succinylcholine }\end{array}$ & $\begin{array}{l}\text { Topical local anesthesia; } \\
\text { light sedation; oral } \\
\text { intubation technique of } \\
\text { e physician's choice }\end{array}$ \\
\hline Myopathy & $\begin{array}{l}\text { Increase } \mathrm{PCO}_{2} 20 \text { to } \\
\text { decrease ventilation; } \\
\text { decrease } \mathrm{PO}_{2} 2 \stackrel{0}{2} \text { to } \\
\text { aspiration, atelectasis, } \\
\text { pneumonia; inspiratory } \\
\text { force }<30 \mathrm{~mm} \mathrm{HG} \text {, and } \\
\text { vital capacity }<10 \mathrm{~mL} / \mathrm{kg}\end{array}$ & $\begin{array}{l}\text { Decrease ventilatory } \\
\text { muscle strength }\end{array}$ & $\begin{array}{l}\text { Risk of malignant } \\
\text { hypothermia with } \\
\text { some myopathies }\end{array}$ & $\begin{array}{l}\text { Oral intubation technique } \\
\text { of physician's choice; no } \\
\text { succinylcholine }\end{array}$ \\
\hline
\end{tabular}

Complications Pneumothorax and other forms of barotrauma result when a patient attempts to breathe spontaneously, unless the ventilator allows an alternative mode for these efforts.

Cost/ cost effectiveness No data available. 


\begin{tabular}{|c|c|c|c|c|}
\hline $\begin{array}{l}\text { Mode of mechanical } \\
\text { ventilation }\end{array}$ & Effect of inspiration & $\begin{array}{l}\text { Effect on } \\
\text { breathing cycle }\end{array}$ & Indications & Risks \\
\hline Controlled modes & $\begin{array}{l}\text { Maintain minimum } \\
\text { minute ventilation }\end{array}$ & $\begin{array}{l}\text { Maintain minimum } \\
\text { breathing frequency }\end{array}$ & $\begin{array}{l}\text { Inefficient gas exchange; } \\
\text { decreased } \mathrm{CO}_{2} \text { response; } \\
\text { weakness too profound to } \\
\text { trigger the device }\end{array}$ & $\begin{array}{l}\text { Barotrauma; } \\
\text { increased sedation } \\
\text { or narcotics } \\
\text { required; muscle } \\
\text { paralysis may be } \\
\text { required }\end{array}$ \\
\hline $\begin{array}{l}\text { Synchronized } \\
\text { intermittent } \\
\text { mandatory } \\
\text { ventilation (SIMV) }\end{array}$ & $\begin{array}{l}\text { Volume controlled, } \\
\text { pressure variable; each } \\
\text { I MV breath fully } \\
\text { supported; each } \\
\text { spontaneous breath } \\
\text { unsupported }\end{array}$ & $\begin{array}{l}\text { Mandatory breath early } \\
\text { in cycle; spontaneous } \\
\text { breathing allowed at } \\
\text { the end of the cycle }\end{array}$ & $\begin{array}{l}\text { "Safe" mode when ventilatory } \\
\text { status is unknown; therapeu- } \\
\text { tic coma, hypothermia, or } \\
\text { hyperventilation }\end{array}$ & $\begin{array}{l}\text { Increased peak airway } \\
\text { pressure; wasted } \\
\text { spontaneous } \\
\text { breathing effort }\end{array}$ \\
\hline $\begin{array}{l}\text { Assisted controlled } \\
\text { mandatory } \\
\text { ventilation }\end{array}$ & $\begin{array}{l}\text { Volume controlled, } \\
\text { pressure variable; } \\
\text { each breath volume } \\
\text { controlled }\end{array}$ & $\begin{array}{l}\text { Breathing rate set at } \\
\text { acceptable minimum; } \\
\text { patient triggers } \\
\text { volume cycled breath } \\
\text { above minimum }\end{array}$ & $\begin{array}{l}\text { Prevent hyperpnea in patients } \\
\text { requiring increased ventila- } \\
\text { tion; prevent nocturnal } \\
\text { hypoventilation; rest patient }\end{array}$ & $\begin{array}{l}\text { Ventilatory muscle } \\
\text { atrophy with } \\
\text { prolonged use }\end{array}$ \\
\hline $\begin{array}{l}\text { Pressure assisted } \\
\text { controlled } \\
\text { ventilation }\end{array}$ & $\begin{array}{l}\text { Pressure controlled, } \\
\text { volume variable; } \\
\text { each breath pressure } \\
\text { controlled }\end{array}$ & $\begin{array}{l}\text { Inspiratory time control } \\
\text { limits high frequency; } \\
\text { device set to maintain } \\
\text { rate above minimum } \\
\text { frequency }\end{array}$ & $\begin{array}{l}\text { Minimize airway pressure in } \\
\text { patients with noncompliant } \\
\text { lungs; optimize inspiratory and } \\
\text { expiratory phases of breathing }\end{array}$ & $\begin{array}{l}\text { Changes in lung } \\
\text { compliance alter } \\
\text { ventilation }\end{array}$ \\
\hline Assisted modes & $\begin{array}{l}\text { Augmented inspiratory } \\
\text { airflow }\end{array}$ & $\begin{array}{l}\text { Breathing frequency is } \\
\text { determined by the } \\
\text { patient }\end{array}$ & $\begin{array}{l}\text { Normal } \mathrm{CO}_{2} \text { response; } \\
\text { ventilatory muscle weakness; } \\
\text { increased airway resistance }\end{array}$ & $\begin{array}{l}\text { Minute ventilation } \\
\text { altered by: } \\
\text { decreased } \mathrm{CO}_{2} \\
\text { response; increased } \\
\text { muscle weakness; } \\
\text { and increased } \\
\text { airway resistance }\end{array}$ \\
\hline $\begin{array}{l}\text { Pressure support } \\
\text { ventilation }\end{array}$ & $\begin{array}{l}\text { Pressure cycled, volume } \\
\text { variable; minute } \\
\text { ventilation depends } \\
\text { on effort and } \\
\text { inspiratory pressure }\end{array}$ & $\begin{array}{l}\text { Frequency depends } \\
\text { on adequacy of } \\
\text { inspiratory support }\end{array}$ & $\begin{array}{l}\text { Weaning from controlled } \\
\text { ventilation; patient requires } \\
\text { artificial airway }\end{array}$ & $\begin{array}{l}\text { Changes in lung } \\
\text { compliance may } \\
\text { radically alter } \\
\text { ventilation }\end{array}$ \\
\hline $\begin{array}{l}\text { Inspiratory positive } \\
\text { airway pressure } \\
\text { (BIPAP) }\end{array}$ & $\begin{array}{l}\text { Inspiratory and } \\
\text { expiratory pressure } \\
\text { delivered via mask or } \\
\text { natural airway; } \\
\text { ventilation depends } \\
\text { on airway patency, } \\
\text { effort, and inspiratory } \\
\text { pressure }\end{array}$ & $\begin{array}{l}\text { Frequency depends } \\
\text { on adequacy of } \\
\text { ventilation }\end{array}$ & $\begin{array}{l}\text { Long term, intermittent } \\
\text { ventilatory assistance; } \\
\text { inspiratory muscle weakness; } \\
\text { adequate bulbar function }\end{array}$ & $\begin{array}{l}\text { Changes in airway } \\
\text { function or } \mathrm{CO}_{2} \\
\text { sensitivity may } \\
\text { radically alter } \\
\text { ventilation }\end{array}$ \\
\hline
\end{tabular}

Standard procedure Assisted modes of mechanical ventilation supplement breathing efforts to maintain adequate minute ventilation. The patient is required to trigger the ventilator to receive a breath. The level of assistance is variable and depends on the patient's effort as well as the level of mechanical assistance [13, Class II]. An assisted mode of ventilation is useful for patients with ventilatory muscle weakness but normal ventilatory drive.

Contraindications Assisted modes of ventilation are contraindicated for patients in whom lung compliance is worsening, pain requires large doses of narcotics, agitation requires heavy sedation, or weakness is too profound to trigger the device. 
Complications Worsening in ventilatory performance can lead to hypercarbia or hypoxia even though the ventilator appears to be operating normally. Continuous pulse oximetry and end-tidal $\mathrm{CO}_{2}$ monitoring are helpful in recognizing hypoventilation in unstable patients.

Cost/ cost effectiveness No data available.

Positive end-expiratory pressure

Standard procedure Positive end-expiratory pressure (PEEP) improves lung compliance, decreases intrapulmonary shunting, and improves arterial oxygenation in patients with acute alveolar injury by improving ventilation to collapsed portions of the lung $[14 \cdot$, Class II].

Contraindications PEEP has remained controversial for patients with poor intracranial compliance or raised intracranial pressure (ICP). Thoracic pressure is transmitted to central venous pressure and right atrial pressure as mean airway pressure is increased. As mean airway pressure increases further, pressure is transmitted to the jugular veins and impedes cerebral venous drainage, increasing cerebral blood volume and raising ICP. The effect of PEEP on ICP is not predictable for several reasons. A Starling resistor-type mechanism may exist in the jugular veins when the head is elevated. J ugular venous collapse may serve as a significant resistance in the transmission of right atrial pressure to cerebral venous pressure in the headelevated position [15, Class II]. Lodrini reported that intrathoracic PEEP-dependent venous hypertension was transmitted to the intracranial compartment without intracranial hypertension for patients in the supine position. PEEP had no influence on patients in the sitting position. In patients with radiologic or clinical signs of increased ICP, however, the combination of head flexion and rotation with institution of PEEP caused a dangerous increase in ICP, even when the patients were in the sitting position [16, Class II]. ICP did not increase with PEEP in headinjured patients with poor lung compliance, but ICP did increase in those patients with poor intracranial compliance and normal lung compliance [17, Class II].

Complications See Contraindications.

Special points PEEP may be used with caution for patients with raised ICP and increased intrapulmonary shunting. McGuire [18, Class II] found that PEEP at $5 \mathrm{~cm} \mathrm{H}_{2} \mathrm{O}$ did not significantly alter ICP in head-injured patients with normal ICP, and that PEEP of $10 \mathrm{~cm}$ to $15 \mathrm{~cm} \mathrm{H}_{2} \mathrm{O}$ did not significantly change intracranial pressure or cerebral perfusion pressure in patients with increased ICP. Positive end-expiratory pressure levels as high as $10 \mathrm{~cm}$ to $12 \mathrm{~cm} \mathrm{H}_{2} \mathrm{O}$ are usually tolerated well [19, Class II]. In those patients with decreased levels of consciousness or poor intracranial compliance, optimal titration of PEEP therapy should include ICP measurement and a continuous evaluation of neurologic status [20, Class II].

Cost/ cost effectiveness No data available.

\section{References and Recommended Reading}

Papers of particular interest, published recently, have been highlighted as:

- Of importance

-. Of major importance

1. Chesnut RM, Marshall SB, Piek J, et al.: Early and late systemic hypotension as a frequent and fundamental source of cerebral ischemia following severe brain injury in the Traumatic Coma Data Bank. Acta N eurochir Suppl 1993, 59:121-125.

2. Chesnut RM, Marshall LF, Klauber MR, et al.: The role of secondary brain injury in determining outcome from severe head injury. J Trauma 1993, 34(2):216-222.

3. $•$ DeWitt DS, Prough DS: Ameliorating cerebral hypoperfusion after traumatic brain injury. Crit $\mathrm{C}$ are M ed 1999, 27(11):2592-2593.

This is a good brief review of blood pressure management in preventing second injury.

4. Chesnut RM: Secondary brain insults after head injury: clinical perspectives. $\mathrm{N}$ ew H oriz 1995, 3(3):366-375. 
5. Tator $\mathrm{CH}$, Fehlings MG: Review of the secondary injury theory of acute spinal cord trauma with emphasis on vascular mechanisms. J N eurosurg 1991, 75(1):15-26.

6. Safar P, Escarraga LA, Chang F: U pper airway obstruction in the unconscious patient. J Appl Physiol 1959, 14:760.

7. Nunn JF: Applied Respiratory Physiology, edn 3. Boston: Butterworths; 1987.

8. Heffner JE: Airway management in the critically ill patient. Crit Care Clin 1990, 6:533-549.

9. Rees SG, Gabbott DA: Use of the cuffed oropharyngeal airway for manual ventilation by nonanaesthetists. Anaesthesia 1999, 54(11):1089-1093.

The use of cuffed oral airway was evaluated for use by unskilled personnel and found to be effective

10. - Yardy N, Hancox D, Strang T: A comparison of two airway aids for emergency use by unskilled personnel: the Combitube and laryngeal mask. Anaesthesia 1999, 54(2):181- 183.

This study compared the use of the LMA with the conbitube as an intubating device for unskilled personnel. The LMA failed less often, but insertion time was similar.

11. - Asai T, Murao K, Tsutsumi T, Shingu K: Ease of tracheal intubation through the intubating laryngeal mask during manual in-line head and neck stabilisation. Anaesthesia 2000, 55(1):82-85.

Thestudy compared the use of fiber optic intubation through a ILMA device with the standard of direct laryngoscopy in cervical spine patients during manual neck stabilization. Intubation was performed easier, faster, and more often successfully with the fiber optic device/ILMA.

12. WongJK, Tongier WK, Armbruster SC, White PF: Use of the intubating laryngeal mask airway to facilitate awake orotracheal intubation in patients with cervical spine disorders. J Clin Anesth 1999, 11(4):346-348.
13. Mad ntyre NR: Respiratory function during pressure support ventilation. Chest 1986, 89:677-683.

14. - Dambrosio M, Roupie E, Mollet JJ, et al.: Effects of positive end-expiratory pressure and different tidal volumes on alveolar recruitment and hyperinflation. Anesthesiology 1997, 87(3):495-503.

The effects of PEEP were evaluated in patients with alveolar collapse PEEP was more effective at increasing lung volumes than increasing tidal volume

15. Toung T, Aizawa H, Traystman RJ: Effects of positive end-expiratory pressure ventilation on cerebral venous pressure with head elevation in dogs. J App Physiol 2000, 88(2):655-661.

16. Lodrini S, Montolivo M, Pluchino F, Borroni V: Positive end-expiratory pressure in supine and sitting positions: its effects on intrathoracic and intracranial pressures. N eurosurgery 1989, 24(6):873-877.

17. Burchie KJ, Steege TD, Wyler AR: Intracranial pressure changes in brain-injured patients requiring positive end-expiratory pressure ventilation. N eurosurgery 1981, 8(4):443-449.

18. McGuire G, Crossley D, Richards J, Wong D: Effects of varying levels of positive end-expiratory pressure on intracranial pressure and cerebral perfusion pressure. Crit Care M ed 1997, 25(6):1059- 1062.

19. Cooper KR, Boswell PA, Choi SC: Safe use of PEEP in patients with severe head injury. J N eurosurg 1993, 63:552-555.

20. Shapiro HM, Marshall LF: Intracranial pressure responses to PEEP in head-injured patients. J Trauma 1978, 18(4):254-256. 